\title{
"When the Cock Crows, the Devil Falls" - a Review of Christian Thought Concerning Birds in Selected Folk Tales
}

\author{
"Gdy kogut pieje, diabeł truchleje" - przegląd myśli chrześcijańskiej dotyczącej ptaków \\ w wybranych opowieściach ludowych
}

\author{
Agnieszka Tańczuk \\ Doctoral School of Quantitative and Natural Sciences, Maria Curie-Skłodowska University, Poland \\ ORCID https://orcid.org/0000-0002-1825-8937•atanczuk@gmail.com \\ Received: 05 July, 2021; Revised: 20 Sep, 2021; Accepted: 29 Sep, 2021
}

\begin{abstract}
In the consumptive world, mysterious things function as magic or superstition, sometimes via tradition, or a relic of a by-gone era. However, we are still afraid to see a black cat, and somebody remembers the celandine (in Polish "jaskółcze ziele"), though nobody knows its connotation with the swallow. The image of birds in folk tales connects the observation of nature, throughout the year and religious holidays, with their consequences for man. Since the beginning, man has admired nature, being afraid of its wildness and primeval power. When one joined it with divinity, it aroused fear even more, but also evoked greater fascination. In this article, I present the essence of myths in folk stories, and its function on the example of birds which have lived in proverbs and sayings. I will also show the variety of references to the cult of Christian saints, the love of the land, and the nature that surrounds us. I would like to show how our attitude towards nature has changed, and what is the function of birds as an element of the environment. I would also like to answer the question; does a modern man need myths to discover his sense of life and realise its meaning?
\end{abstract}

Keywords: birds, nature, Christianity, humans, folk tales, myth

Streszczenie: W świecie nastawionym na konsumpcjonizm i zysk, to, co tajemnicze funkcjonuje jako magia, zabobon, czasem jako tradycja, relikt zamierzchłych czasów. A jednak w życiu codziennym wciąż obawiamy się czarnego kota i ktoś jeszcze pamięta, że na coś dobre jest jaskółcze ziele, choć nie wie jaki związek ma z tym wszystkim jaskółka. Obraz ptaków w kulturze ludowej łączy w sobie obserwację przyrody, jej rocznego cyklu oraz świąt religijnych, których daty w kalendarzu zbiegają się z nastawaniem cieplejszych bądź chłodniejszych dni i ich konsekwencji dla człowieka. Człowiek od początku zachwycał się naturą, jednocześnie obawiając się jej dzikości, jej pierwotnej mocy. Gdy połączył ją z boskością, to jeszcze tylko bardziej roznieciło strach, ale i zrodziło tym większą fascynację. W niniejszym artykule przedstawiam istotę mitów w kulturze ludowej, jej funkcję i na przykładzie gatunków ptaków, jakie funkcjonowały na co dzień w opowieściach i przysłowiach, pokazuję mnogość odniesień do kultu świętych chrześcijańskich, umiłowanie ziemi i przyrody, która nas otacza. Chciałabym pokazać, jak zmieniał się stosunek człowieka do przyrody i jaką funkcję do spełnienia mają ptaki jako elementy natury oraz odpowiedzieć na pytanie czy dzisiejszy człowiek potrzebuje mitów, aby znaleźć sens życia i odkryć jego znaczenie.

Słowa kluczowe: ptaki, przyroda, chrześcijaństwo, człowiek, opowieści ludowe, mit 


\section{Introduction}

I have always been interested in the interpretation of natural phenomena by people, since my early days, their ability to see the signs of divine intervention in every tree, in each rock. Today, the majority of people do not pay attention to minor things, creatures that surround them, or even incidents that happen to them. People have changed what was previously crucial, in understanding the sense of life, into superstitions, and neglect them, treat them without interest, as being childish and a waste of time, especially when "time is money" to them. The aim of this paper is to show how modern people have changed their understanding of animals, in comparison to the anonymous authors of folk tales, in which the presence of animals was treated with respect and connected with saints and the Divine. Nowadays, we know more, and that is why we do not see any reason to explain something, which seems inexplicable, using mystical terms and predictions. I wanted to find out whether the knowledge of simple people about the behaviour of animals, was scientific enough, and if not, how did they cope with presenting birds in such details and with imagination? Was it biology or religion? Or Christian ethics to be more precise - passed from one generation to another, or a mixture of both? Were the animals presented in these stories wild enough, or maybe only anthropomorphised creatures in the service of men? Do we still rely on nature, searching its guidance or not? The other issue is to find out the answer to the question: are myths and folk stories needed now, or maybe should they be abandoned as something not serious, a form of baloney, only for children?

In the first chapter, I would like to discuss human power over nature, man's drive to learn from experience, to observe, and then translate the world, in order to feel comfortable and satisfied, to extinguish the fear which burns inside them. Chapter two focuses on the need for myths, to explain the components surrounding man, sanctifying the landscape, and the eternal struggle to survive, and be grateful at the same time. The third chapter deals with seasonal changes, the very cycle of nature, and how did people from folk tales explain the migrations of birds, their behaviour, or even their appearance. Chapter four is about personification of the divine intervention in people's lives, and how birds became symbols of purity, renewal, or light. In chapter five, I gathered the stories connected with birds' presence in Jesus Christ's suffering on the Cross, and the consequences of their actions. Chapter six is devoted to moral values that people could learn from birds, to get rid of vanity, and become more wise, pious, and vigilant. The last chapter presents the good side of birds as well as the dark side, and how they were rewarded for help or punished for disobedience. The article, overall, deals with cross-curricular issues such as biological or scientific, philosophical, and theological, combining literary traditions and the modern perspective.

\section{Human against nature}

Human beings since the beginning of their existence, have been trying to tame nature as if to reflect God's words: "be fruitful and multiply, and fill the earth" (Gen. 1:28); in Polish translation, it has more the sense of possession, and using power or force over other creatures. Man was afraid of the world that was surrounding him, he was scared of the vast and unmeasurable unknown. He had to learn how to find food, stay warm, and protect his family, but also through gaining knowledge about other beings that lived near him, and the elements on which he depended, a human became more confident, though yet not powerful. By getting acquainted with everything he came across during his life and wanderings, he was becoming less frightened, and could provide himself with stability and comfort.

The fear has been co-existing with the fascination of the universe: its power, its endless cycle where everything from the blade of grass to the great whale had its place, and 
every season had its time. Man admired the construction of the world and the beings, as well as the mechanism that pushed them forward. He wanted to learn strategies to survive, and then to improve them to become self-sufficient, and what is more, in harmony with nature. This specific mixture of fear and fascination - tremendum et fascinosum (Tańczuk 2010, 160) accompanied men through all the centuries, however, with a different strength and scope over the years. It was here that one may find the origin of a myth, the very core of it, and the exact reason for it - myths as a way to understand the world, a lesson to learn from its ideal, primordial order to tame it, and to make it one's own. Obviously, myths are not only that, there are a lot more - they were, and still are, to some extent, a human's cravings, desires for the divine, sacrum to make profanum easier to bear. Myths were also the way to name every single being, to understand processes propelling the universe, and to make the local setting sacred and more meaningful since "the sanctification of the local landscape is a fundamental function of mythology" (Campbell 1991, 69).

Nature seemed perfect to man, and was long before him, so it had to be created by Someone or Something far more powerful than he is, far wiser and more thoughtful. Someone or Something who invented every single creature, had to have a master plan, but still needed man, who would continue the process of creation - today, we would rather say "invention" or "discovery", nevertheless, a human was supposed to continue the work of the Divine Creator, had to improve it, add something to it, and even change it, but always in the way it was planned to be. All of it had a purpose - to help humans, without interfering too much into nature, in order not to destroy it; and here there is a thin and sensitive line, and an issue to be covered by other writers, some other time. In a way, myths were the thread joining human nature with $\mathrm{Na}$ ture itself. Campbell calls it "a harmonising force" (Campbell 1991, 47). From that perspective, one might conclude that myths are our protection from going too far in the process of altering the world.

\section{Myths - the mirror of the divine}

Man felt superior over other beings, but on the other hand, he understood that he could not own everything. He used the world for his own purposes, but he knew that he was dependent on its resources. In this manner, myths are not only our connections with the High Spirit, but also the source of primaeval energy that everybody needs to live. Thus, man observed nature, named it, and was making symbols out of it to comprehend more, to make his life easier, to be the legitimate part of the vast universe as a partner, co-being, and co-worker of the Creator to feel safe and happy. The landscape, and every single piece of it, had to be sacred, since it existed before us, and it already had the knowledge or instinct to survive, the power that man wanted to possess. $\mathrm{Hu}$ mans translated the world into symbols, and made all beings sacred, and learnt from it for their own good. This part of the world became something sacred and had to be respected, just as Campbell writes that: "every land should be a holy land. One should find the symbol in the landscape itself, of the energies of the life there. That's what all early traditions do. They sanctify their own landscape" (Campbell 1991, 71).

Obviously, at the beginning, man did not learn from books, but from experience. He was watching, touching, smelling, tasting, and using all the senses he had. He also took part in the process, as he could not afford to stand aside; he had to be in it. Man had to be active to balance fear with admiration, so the latter helped him to be a better improver of the world, and not only a passive observer. Nevertheless, the observation of Nature was very crucial - by doing this, man started to understand the essence of life, started to see the repeatable fates of the universe, and tried to use it for his advantage. In every creature, he saw the Divine plan. For example, trees were wise, because they 
had been living for so long and could touch the bright sky with their branches and feel the darkness of the Underworld with their roots. Trees gave man fruit to eat, shelter from heavy rain, and the scorching sun; and whilst his children could climb a tree for fun, fallen twigs were used to start a fire to keep the family warm, and its parts, collected in a specific period of time, could heal. The tree itself can be seen as a metaphor for the Universe. And what about the animals there were so many of them? Some were flying in the air, some knew the very depth of the ocean, some were crawling, silently, next to man's feet, some could kill man, some were killed by him.

\section{Birds, seasons and saints}

In the bestiaries, old medieval texts, written to explain Christian ethics on the examples of animals, there were five animals mentioned, which were considered to use their senses better than humans: the pig had a perfect sense of hearing, the lynx its sight, the vulture excelled in its sense of smell, the monkey had an ideal taste, and the spider was a master of touch (Rosiński 2007, 55). Man both admired those abilities, and he envied the animals. He feared the consequences of meeting face to face with them. That is why, many animals, or even groups of animals, were presented in various myths in an ambiguous way, joining negative and positive qualities at the same time.

Man has always envied birds: for their ability to fly, for their majestic wings, their contact with the sky and the Divine entity, above and beyond his imagination. From Icarus, the Wright Brothers, and to this day, man has invented aircraft to feel like a bird. This admiration was visible in every aspect of life: from the everyday work in the fields, to holidays and celebrations in respect for natural elements, and then saints and holy men. The weather, seasonal changes, and catastrophic events were explained through Nature, as an act or warning of the Greater Force.
When we browse through the folk calendars, known in Poland, and also in some other Slavic countries, two things are correlated: the part of the year or the season, and the day when a certain saint is being remembered. Saint Veronica ( $13^{\text {th }}$ January) is a harbinger of wild ducks, which start laying eggs. Saint Agnes (21 $1^{\text {st }}$ January) releases the lark from the pouch indicating that spring has come, so does Saint Dorothy on the $6^{\text {th }}$ of February (Pióro 2012, 15, 36). In February, when the cranes are flying high, spring will come soon in time (Pióro 2012, 33). Lapwings are supposed to migrate on the nameday of Saint Kazimierz ( $4^{\text {th }}$ March) and there is a story behind it. The young prince bought the bird which was to be sold on the market and let it free. Since that time, birds have been always flying back to him in spring (Pióro 2012, 57). Saint Francis summons a wagtail $\left(2^{\text {nd }}\right.$ April), in this case this saying is about the western yellow wagtail (Motacilla flava), since the white wagtail (Motacilla alba) can be seen even at the beginning of the year (Pióro 2012, 29). Storks are seen as heralds of spring, symbols of prosperity and happiness. There are many proverbs and sayings where storks play the leading role, and one may find them next to Saint Matilda (14 ${ }^{\text {th }}$ March), Saint Gertrude ( $17^{\text {th }}$ March), Saint Josef $\left(19^{\text {th }}\right.$ March), Saint Francis $\left(2^{\text {nd }}\right.$ April), Saint Isidore (4 ${ }^{\text {th }}$ April) or Saint Adalbert ( $23^{\text {rd }}$ April). If the storks fly away before the name-day of Saint Bartholomew $\left(24^{\text {th }}\right.$ August), there would be a harsh winter. Crossed legs of a stork form an " $x$ " which is the first letter of the Greek word "Christ", as well as the Cross of Saint Andrew, the patron saint of Scotland (Pióro 2012, 63). Saint Michael's day seems to be an important turning point in seasonal changes, if there are some storks left until the $29^{\text {th }}$ of September, there will be no frost in December, but if they fly away up to this day, the winter will be very cold (Pióro 2012, 189; 215).

Once it was believed that swallows sleep on the bottom of ponds or lakes and Saint Mary wakes them up in spring, thence, there is a saying that when the Christian Church 
celebrates the Annunciation to the Blessed Virgin Mary (25 ${ }^{\text {th }}$ March), all the swallows emerge on land, and whoever sees the swallow for the first time in spring, has to wash his face and then, he will be fortunate (Pióro 2012, 84). There is a legend saying that Saint Mary is very grateful to swallows, as those birds protected the small Jesus from troublesome flies, when the Holy Family were running away to Egypt (Pawłowska 2003). If swallows appear before Saint Joseph's Day $\left(19^{\text {th }}\right.$ March), spring will come early that year (Pióro 2012, 72). If the cuckoo still sings after John the Baptist's Day ( $24^{\text {th }}$ June), autumn will be warm (Pióro 2012, 177). Of course, there has to be a time during the year when birds become silent, when the winter's rest is upon them. In Christian folk tales, people explained that fact in numerous ways. One is that Saint Francis preached the word of God to all birds, and after he finished, he made a sign of a cross and the birds flew to the four corners of the world, to come back again and sing to him, while preaching once more (Pióro 2012, 72). The other is connected with Saint Vito, who could not hear the words of God because the nightingale was singing too loudly, so there is a proverb that on this day, birds become silent $\left(15^{\text {th }}\right.$ June) (Pióro 2012, 135).

Birds from Christian stories are depicted in various ways: they can be the symbol or even personification of God himself, they can be helpers of the Creator, graceful worshippers as a part of Nature, which was brought to life by God, and always praises the Lord. Very often, birds are used to show people some good examples; they serve as a tool, or an instrument for moral teaching.

\section{Birds as personifications and symbols of divine intervention}

The best-known example of God appearing on earth in a shape of a bird is during the baptism of Christ, when the Holy Spirit shows Himself to John the Baptist, as a dove or a pigeon. There were also seven doves flying above the Holy Cross, when Jesus was dying, which symbolises the seven gifts of the Holy Spirit. Pigeons were sacrificial birds considered to be pure and innocent, symbols of the chosen nation of Israel helpless and oppressed (Kruszona 2008, 46). Later, these birds were related to all poor and innocent people, as a symbol of grace and modesty (Rosiński 2007, 63). In addition to this, in Jewish tradition, pigeons, similarly to ducks and geese, were kosher, and could be eaten; 24 other birds described in the Bible were unclean and forbidden to be eaten (Kruszona 2008, 45). Doves were also symbols of a new life: when Noah released the dove for the second time, it returned with an olive twig. The third bird remained on earth to start a nest, giving the sign that the waters had gone, and the land was ready to be inhabited once more (Kruszona 2008, 46). There is another symbolic gesture suggesting how important pigeons are in Christian tales. Saint Francis freed the turtledoves, which were supposed to be sold on the market, showing that they are like human souls, which will be free at the end with God (Pióro $2012,95)$. The whiteness of doves' wings is also the colour of angels' wings, and the symbol of the resurrection (Chadd 2016, 9).

The second bird related, specifically, to the Messiah is the pelican. In the Book of Psalms (Ps 102:6), one reads "I resemble a pelican of the wilderness." In his hymn, Adoro Te Devote, St. Thomas Aquinas writes the following about Jesus (St. Thomas Aquinas 2017):

Pelican of mercy, Jesus, Lord and God, Cleanse me, wretched sinner, in Thy Precious Blood: Blood, whereof one drop for humankind outpoured Might from all transgression have the world restored.

A medieval story tells us about a mother pelican, who wept for three days after her chicks were killed by a snake. After those days of mourning, she pecked her body with her beak, and brought the children back to life, with her own blood becoming the symbol of Jesus Christ, who redeemed all the sins of the world with His own Blood 
(Bruce-Mitford 1997, 64). Peregrine from Opole (sixteenth century) explains in his essays, that the snake is the devil and he will always hate the pelican-Jesus (Peregryn z Opola 2003; Kruszona 2008, 144). There is also another version of this story saying that it was the mother pelican who killed her children, and then regretted her deed and gave them life again. Similarly, in the Bible and the old bestiaries, God is merciful and will forgive us our disobedience, and when time comes, He will resurrect people (Sasor 2006, 95).

In old bestiaries, full of animals and beasts, one may find another creature which might be included in the group of birds, because of its appearance. For the first Christians, the phoenix was the symbol of Christ (Bruce-Mitford 1997, 31). There is only one phoenix in the world. Its feathers are the colour of wax and roses. It lives up to five hundred years, and when it is old, it collects dry wood and makes a pile out of it. He makes it where the sun shines to the hottest degree, climbs onto it, and strikes with its wings to start a fire. It burns to ashes and is born again, first as a little worm, and then as a great fiery bird (Sasor 2006, 121).

In many cultures, the rooster is like a wake-up call for people and their souls (Chadd 2016, 155). In Scandinavian myths, for example, it proclaims the end of the world, actually there are three of them: red-feathered from Jotunheim, rusty-feathered from Niflheim, and the one with golden feathers from Asgard. In the New Testament, it is a cock who reminds Saint Peter of his oath. The rooster becomes the symbol of Christ, who has the power to divide light from darkness, who claims victory over evil forces, and who is the resurrection itself (Bruce-Mitford 1997, 64). Saint Ambrose, in his hymn: Aeterne rerum conditor (Maker of all, eternal king), compares Christ and the rooster as a symbol of new life that is coming to bring faith and hope to those who doubt (Kowzan 2007, 127). Although one of the poultry, not very big and terrifying, the cock is the only weakness of the basilisk, a snake-like beast which has an ability to change into stone, only with its eyes (Kowzan 2007, 131). The rooster's voice can chase away the demons. There are some sayings and proverbs describing this: "When the cock crows, the devil falls" or "Temptations don't mean a thing, when the rooster sings" ${ }^{\prime 2}$. The rooster had the power to reverse evil, bad luck, and all the dangerous attempts of the unclean spirits (Kowzan $2007,123)$. The rooster, which is crowing as the third guard announces the dawn, forcing dark forces and their allies to flee. It is interesting to add a story from the Jewish tradition. The Jews distinguished four types of guards: the beginning of the guard, the midnight guard, the cocks-crowing guard, and the mourning guard (Kowzan $2007,123)$. The silhouette of a cock on churches was a kind of a warning to Christians to acknowledge their faith (Chadd 2016, 54). It is believed that roosters crow all night during Christmas Eve (Chadd 2016, 54). Also, the hen with its chicks represents Christ and His believers (Bruce-Mitford 1997, 64).

A lark is a bird of daylight and sun. Its song in the morning announces that the light rules again over darkness, that there is a time free from demonic powers lurking for the human soul (Kruszona 2008, 156). As such, the lark is a symbol of Christ - the bird with healing powers. When there is a lark in the room, and it looks into the sick person's face, he would be cured; if not, the person would die (Sasor 2006, 65). It is also Mary's bird, as the female is always clean and neat, humble and submissive to her husband, not provocative, but pious, and never neglects her husband at the expense of her children (Libera 2007, 211). There are stories similar to those about swallows telling us that

1 "Kiedy kur pieje, diabeł truchleje" (Kowzan 2007, 123), "When the cock crows, the devil falls" (free translation by the author).

2 "Pokusy władzy nie mają, gdy już kurowie śpiewają" (Kowzan 2007, 123), “Temptations don't mean a thing, when the rooster sings" (free translation by the author). 
larks sleep in winter in mouse holes, or under the rocks, and Saint Mary wakes them up in spring, and then protects birds' nests from birds of prey, using Her own robe (Pawłowska 2003). A swallow is also a manifestation of Jesus the Healer, since it can bring one's sight back, as she does, when someone gouges out her children's eyes she flies for a herb known as celandine (Chelidonium majus) and heals them (Sasor 2006, 81-82).

The eagle is a royal bird. Although in the wild it feeds also on carcasses, in Christian folk tales, it is considered to be majestic, strong, and holy. It also symbolises the Ascension of Christ (Bruce-Mitford 1997, 66). In the Middle Ages, an eagle was seen as a prayer flying straight to God (Bruce-Mitford 1997, 66). The first Christians believed in the power of renewal, similar to the one the eagle possessed. It could become young again - but when it felt tired and could hardly see, the eagle flew to the sun, and its eyes were burnt by it, and made its body weak, so it had to land in a spring it had previously chosen. It had to bathe in it three times, and it regained its youth. Saint Augustine compared the eagle's immortality to man's eternal life in heaven (Kruszona 2008, 98).

The swan can be a symbol of both: Jesus, as well as His Holy Mother. Its white feathers stand for the purity of Saint Mary, while its singing symbolises the suffering of Jesus Christ (Pióro 2012, 290). It was also believed that angels have swans' wings, so the birds may be the messengers of God, and God wants to be admired by His creations (Kruszona 2008, 84).

The peacock is an interesting creature, because in old bestiaries it is an example of a vain man, but in folk legends, it is described as a symbol of Christ, who resurrects. In the same manner, the peacock's feathers grow up again when it loses them. There is also another curious thing: Saint Augustine wrote about the belief that the peacock's flesh does not decay for at least 30 days as a symbol of immortality (Chadd 2016, 146).

The birds from the Corvidae family have most often negative connotations in Christian folk tales, yet, as I have mentioned before, they can also be dualistic in their symbolism. Rooks, as with crows and ravens, are cursed for having associations with the devil, because of their black feathers, their voice, and their fondness of meat. However, rooks can be very pious birds, too. There is a belief that those birds do not build their nests on only one day in a year The Ascension of Christ. They sit on trees to show respect to their Creator, but also do something more. When they see a man who is dressed improperly, going to church on Easter Sunday, they drop their excrements on him (Chadd 2016, 28).

\section{Birds next to the Cross}

In many stories, birds have been rewarded for being good to Jesus Christ, hanging on the Cross. When most of His dearest friends and followers abandoned Him, some birds remained and tried to ease the pain.

A goldfinch tried to help Jesus and started to pull out thorns from His head and a spike from His eyebrows, and a drop of Saviour's Blood fell on it, that is why it has red-coloured feathers around its beak (Bruce-Mitford 1997, 66). Due to this fact, the goldfinch can also heal itself; and feeding on thistles, never hurts it (Chadd 2016,128 ). The goldfinch became a symbol of the human soul, suffering and tormented (Bruce-Mitford 1997, 66). There were also other small birds helping to ease Jesus' pain such as a lark, which helped a goldfinch in pulling thorns (Pióro 2012, 22), or a robin who was pulling the nails from His hands and feet, and hence it has a ginger neck (Bruce-Mitford 1997, 67). The robin also helped baby Jesus, after He was born, it either brought fire from heaven or fanned with its wings so quickly as to alight an incandescent coal, to keep little Jesus warm (Chadd 2016, 137). Meanwhile, a wren is called "God's little hen" in Normandy, as it 
brought moss and feathers as a blanket for Baby Jesus (Chadd 2016, 294). A crossbill's beak has this kind of a shape because it was believed to have pulled out nails from Jesus' body hanging on the Cross, and now it is twisted. Crossbills also have the colour of blood on their feathers (Chadd 2016, 127). According to early Christian stories, crossbills build their nests at Christmas, and their young are hatched at Easter (Chadd 2016, 127). Legends concerning the Crucifixion, could not omit a stork, the emblem of many countries, and a lucky bird around the world. The Christian Scandinavians believe that the stork cannot sing, but only clatter because they screamed to Jesus to hearten Him: "Styrket!" which means "Strengthen ye!"3 (Chadd 2016, 23). In Greece, they are the attribute of Athena, the goddess of wisdom, in China, they bring luck, and in Spain, they participate in Christ's suffering on the Cross. In the old days, owls could sing, but then they saw the tormented Jesus, and they started to scream out of grief: "cruz, cruz" which means "cross" in Spanish (Karczewski 2014, 31).

Birds' natural behaviour and their relations with humans have been explained in relation to the Saviour Himself. Christians in France believe that swallows can build nests near or at human houses, because they were good to Jesus on the Cross and tried to pull out the thorns from His head (Kruszona 2008, 15). On the other hand, magpies pecked Jesus' legs and head and were banished from human neighbourhoods (Kruszona 2008, 14). Swallows sang a sad song after Christ's death, whilst starlings did not, and that is why they were cursed (Chadd 2016, 41). Similarly, the magpie did not mourn after Jesus died, and had to sit on a tree nine times, before it could lay an egg (Chadd 2016, 9). Sparrows betrayed Jesus in Gethsemane by screaming loudly, and when He was dying on the Cross, they were still screaming that He is alive (Chadd 2016, 274). The lapwing, which was so helpful to Saint

3 "Be or stay strong" in modern English.
Mary in some stories, was mocking Jesus on the Cross, and laughed at him, and that is why it has to wander and migrate in autumn and spring every year (Chadd 2016, 246).

\section{Birds as examples for men}

Do animals have morality, or do they just fight to survive and raise their young, subjected to the law of the fittest? In Christian folk tales, they adapt the roles of men, to be an example for them how to behave, to deserve the love of God and His mercy; they are the personification of animals, but still remain embedded in the world of nature.

The ideal man, just as God wants him to be and as it was believed, has pure thoughts and words, or speaks wisely and not lustfully, and also has a pure heart. We can learn a lot from animals, which are driven by instinct, but somehow closer to an ideal God's creature. The rooster was mentioned before, but its symbolic meaning seems to be very wide and important in folk stories, probably because it is one of the animals close to men, and its presence in the Bible is very significant. It is best known for its call, yet it does not crow in a reckless or mindless way. First, the cock hits its wings three times, which gives it time to think about the words it would say. In moral stories, the cock is an example of a thoughtful man who can speak eloquently, and wisely, following the words: "but I tell you that everyone will have to give account on the day of judgement for every empty word they have spoken" (Mt. 12:36) (Sasor 2006, 37). Similarly, the crane is also a symbol of not saying things idly, and its long neck helps it to act that way. Before a bird eats something, it has to twist its neck three times - this should suggest that people think twice, or even thrice, how to speak and what to speak, to consider every matter first in one's heart (Sasor 2006, 49). The crane is also an example of vigilance. When one bird sleeps, the other stays awake and watches, always having a stone under its leg to prevent it from falling asleep. There is a message in folk tales that we should do the same, because the devil always tempts 
and never sleeps (Sasor 2006, 79). In a story about a king and his sons, the dying father tried to find the best king among his children, and asked them what were their greatest wishes: the first one wanted to be rich, the second wanted to be a starling, because it is always surrounded by many friends and is very grateful, though without any special honours, whilst the third one wanted to have a neck like a crane, so that it had to twist it three times before he could say something. Being like a crane, he would never fall or get lost in life, he would be wise, and therefore, happy. The third son became king (Sasor 2006, 49-50). The number 3 appears very often in many folk tales on Christian grounds - it stands for the Holy Trinity, the number of days Jesus stayed in a grave, the magical number in many cultures. Satan mocks number three and multiplies it to appear better and stronger than God the devil tries to use the same methods as God, to be more successful in his cunning means of temptation.

Some of the stories are absurd or even ridiculous, without scientific premises, but were composed to proselyte moral values, and choose the right path of life. A partridge may be one example of a fancy lesson with moral foundations. When a female partridge lays its egg, the other steals it and takes it to its nest, one by one. However, when the chicks are hatched, they run away to their true mother - so should man listen to his true parent, which is the preacher, and not to the voice of the devil, who always wants to abduct human souls. The Latin name of this bird perdix comes from the word "to lose", since one of the mothers loses its eggs, and the other loses its chicks (Sasor 2006, 129). Another tale is about a peacock, which earlier, was a beautiful example of the perfection of God's creations, but here is presented as a vain man, who boasts of his colourful feathers, yet does not see the ugliness of his naked legs. They are so awful that he has to lower his tail. There is a hidden message to all men in this story: "for what do you pride yourself on your pretty feathers, if you lose everything, when you provoke the Heavenly Lord to anger?" (Sasor 2006, 81-82).

\section{Good and evil birds}

The fight between the bird and the snake symbolises the eternal war of good and evil (Bruce-Mitford 1997, 62), yet not all birds are depicted as good and godly creatures. Some of them were assigned to demonic powers by men, and some of them made wrong decisions at the beginning of time (also according to men). Why? Because man does not want to be the only one being in the world, who falls into temptation, and does wrong things.

Kindness and holiness bring goodness. Though dark in many stories, blackbirds protect houses from thunders, just like the storks do. Saint Kevin ( $3^{\text {rd }}$ June), the hermit who lived for one hundred and twenty years, was praying eagerly and for so long, that he did not notice that blackbirds had built their nest in his entwined hands, female birds had laid eggs, and the chicks had hatched (Pióro 2012, 127). When Saint Mary's mother - Saint Anne, was praying to God for a child, she saw a nest with sparrows, and it was a sign for her that God had listened to her prayers (Pióro 2012, 166).

In the phylum of birds, the raven is the best example of being depicted as pure good sent from heaven above, to teach humans how to live and cultivate the earth, as well as having demonic powers, or even being the devil incarnate, a thief, the harbinger of death, known by all: God, Satan and shaman (Kruszona 2008, 141). In the Bible, animals are divided into the clean or unclean ones. The raven, as a scavenger, was classified into the second group, together with vultures and crows. Yet, the raven was also wise, it knew the future, it was the messenger wandering around the worlds of the living and the dead. It was bringing half a loaf of bread to Saint Paul every day (Pióro 2012, 247). There was also a story about Bishop Edwin from the eighth century, about the raven who brought an evil omen, the fortune only 
wizards could interpret. The bishop ordered the killing of the bird, and told his believers that the raven could not predict the future, since it did not foretell its own death. However, the bishop did not understand the fact that the bird was meant to bring the message, and even if it knew about its own death, it would do it anyway, since it was the messenger of the spirit, and it was not afraid of dying (Bates 2005, 148-150).

When ravens were around, they foretold war, destruction, and death. Ravens fed on dead corpses after the battle. They can be an allegory for the devil - just as the raven first eats the eyes, and then the brain, the devil takes away the eyes of a human's soul, and his memory (Sasor 2006, 59). The raven was cursed by Noah himself, because of its fancy for carrion. There is a story when Noah released the raven from the Ark to seek dry land, it did not come back, because it saw a carcass. Since that time, it would be despised by people, and has to eat carrion for the rest of its days, through all generations. On the other hand, from the biological and ecological point of view, ravens help to clean the world, and according to Zoroastrians, these birds are considered clean (Chadd 2016, 262).

Its black colour was the obvious symbol of darkness and night (Bruce-Mitford 1997, 92), yet the ravens were thought to be white in the beginning. There are many stories about being touched by the smoke, because of wicked men. There is also one with Christian connotations. When a raven's chicks are hatched, they are white, and their parents leave their children, and do not feed them until they are black. During that time, God gives them food: dew and wind (Sasor 2006, 59).

As with black ravens, rooks, crows, and even blackbirds, were considered evil birds. The magpie was even worse, and seen as not only demonic, but also wicked and mean. It did not show itself in a good light during Christ's suffering, but it was evil, even earlier in the history of the world. It is cursed because of its "big mouth" and when the world was sinking during the Deluge, it was only sitting and talking all the time; that is why Englishmen call it a "chatterpie" (Chadd 2016, 9). In Ireland, when a gossip dies, magpies knock at his or her window, and take the soul away (Chadd 2016, 258). It is said that the devil entered the body of a magpie and started to use bad language. When Noah built an Ark, these birds, were the only animals, that did not board the ship. Scottish people believe that the magpie carries a drop of the devil's blood under its tongue (Pióro 2012, 17).

Creatures that hunt at night-time have always been considered evil, as something unnatural and weird, and a nighthawk is one of them. One of its Polish names is "kozodój" which means "the one that drinks goat's milk" and had something in common with "ignis fatuus" or the wildfire (Kruszona 2008, 67). In Indonesia, it is believed that it plucks out men's eyes in their sleep (Chadd 2016, 244). Of course, this has nothing in common with scientific research of this bird's behaviour.

Obviously, among birds, owls have been treated with fear, hatred, and disgust. Many birds, now protected, have been killed because of superstitions and foolishness. Owls were considered an ill omen, a sign of death or misfortune (Bruce-Mitford $1997,67)$. In the names of species, one will hear the names of demons and dark forces. Latin "strix" like in the species of owls Strix uralensis, Strix aluco or Strix nebulosa ${ }^{4}$ means a night demon, which has two hearts and souls, as well as two dental arches, and drinks the blood of infants (Pióro 2012, 39). The other one is "bebok" from the Latin Bubo bubo or the eagle owl. Some believed that the devil, himself, changes into an owl at night, and there is a saying "when owls sing, the devil grins" (Pióro 2012, 89). There is a sub-species of a little owl which is called Athene noctua lilith. The old tale says that Lilith was the first wife of the Biblical

\footnotetext{
4 "Strzyga" in Polish.

5 "Gibberish" in English.
} 
Adam. It was she, and not Satan in the form of a snake, that persuaded Eve to pick up the fruit in the Garden of Eden (Pióro 2012, 110). Lilith chose the life of a demon, because God did not want to give her what she desired - to be equal to her husband, Adam. At night, she was changing into an owl, seduced men, and gave birth to lots of demons like herself. She also kidnapped children straight from their beds, and that is why there was a special ritual protecting the young ones from her power. Parents had to write an inscription on the child's bed: "Adam and Eve without Lilith", together with the names of three angels: Sanwi, Sansanwi and Samangelaf. Those three were sent by God to bring Lilith again to Adam, but she wanted to become a mistress of Samael, the lord of evil forces, and remained cursed. In anger, Lilith spoke the Name of God, floated in the air, and fell into the Red Sea (Kruszona 2008, 70). After destroying the sinful cities of Sodom and Gomorrah, only owls stayed there. According to the first Christians, the owl was the bird of the Jews, because they chose the darkness of their faith, instead of the Christian one (Chadd 2016, 286).

It was believed that people who were born on the day of the owl - the longest day of the year - were aggressive, had personality disorders, and a tendency to commit crimes (Karczewski 2014, 31). When somebody heard its call near the cemetery, one soul was taken by it. People prayed in these words "Go, off you go, into a church's hole"6. The sound of the Polish word for "go" - "pójdź" - suggests the species of an owl pójdźka, which is a little owl (Athene noctua) (Karczewski 2014, 31). The only way to get rid of evil powers or news brought by an owl, was to kill the bird. It was not a sin, but a godly deed. Yet one had to be careful, since an owl could rise up from the dead, because it was

6 "Pójdź, pójdź w dołek pod kościołek" (Karczewski 2014, 31), "Go, off you go, into a church's hole" (free translation by the author). considered to be a messenger of the Underworld (Karczewski 2014, 31).

Even as tools of evil, owls were used in various ways to help or even cure people. Due to their contacts with other worlds, people used owls to find missing people, or lost objects (Karczewski 2014, 32). In the fifteenth century, madness could be cured by sprinkling ashes from an owl's bones onto a madman's eyes. If somebody had problems with alcohol, he had to eat raw an owl's eggs. To be cured out of gout, one had to put a lineament on infected places, made out of the owl's meat, simmered in a pot, and then ground with a wild boar's fat. Owl's grease was an excellent medicine for skin irritations and burns. Migraine could be stopped when somebody put an owl's bone marrow into his nose. For epilepsy, the best treatment was to eat a soup made from an owl's eggs, prepared after a full moon night. Oil, together with owl's blood, was perfect to get rid of lice. For bedwetting - owl's bile, for facial paralysis - a massage made with owl's blood or with the use of an owl's heart. Also, the owl's heart under the armpit, protected against rabies and dog bites (Karczewski 2014, 32-36). It is interesting that owls could help in so many cases having such an evil origin; how can a devil make something good, or rebel against another devil? - one may compare it with the words of Jesus Christ: "if Satan drives out Satan, he is divided against himself. How then, can his kingdom stand?" (Mt. 12:26).

By observing owls, one might predict the weather, or even the future. A woman sleeping with an owl's heart could only tell the truth, and all her secrets were uncovered, the same was with man, but instead of the heart, the feather was used. During Scottish weddings, the owl is a sign of wisdom and a new beginning, when it flies to the first man and sits on his shoulders, with wedding rings tied to its legs (Karczewski 2014, 32-36).

The more we read, the more we find out that birds in folk stories are not depicted in a one-sided way only, they are not only 
black or only white, only good, or only evil they have their good and dark sides, just like men, and sometimes, they also rebel against the Creator. At the beginning of time, God asked birds to dig streams and water bodies for all creatures to use. Storks and herons worked hard, only the kite did not want to help. For such insubordinate behaviour, God forbade it to drink water from lakes, streams, and ponds, and when it wanted to drink, the kite had to call for it with its squeaking voice, and then the rain falls from the sky - that is how the Polish saying was composed: "wants the rain as the kite does" (Pióro 2012, 59). The first stork was a nosy peasant who opened the sack he was not allowed to open - all reptiles and amphibians came out of it, and God turned the farmer into a stork, and commended him to eat all of it (Pióro 2012, 63-64). The sound of a lapwing can be called "tjuvit" - it is from the Swedish word "tjuv" which means "thief". It feels guilty since it stole the pair of scissors from Saint Mary, while She was sewing (Chadd 2016, 246). Even small and very common birds may be evil. In Ireland and Great Britain, swifts are considered to be the birds of Satan (Chadd 2016, 242), sparrows carry the souls of the dead and act like prophets predicting weather, and when the woodpecker crows, the devil is near as one German saying suggests (Chadd 2016, 64).

\section{Conclusion}

In our post-modern world, mysterious things function as magic or superstitions, sometimes as a tradition, or a relic of a bygone era. However, we are still afraid to see a black cat, and somebody remembers the celandine (in Polish "jaskółcze ziele"), though nobody knows its connotation with the swallow.

The image of birds in folk tales connects the observation of nature, throughout the year, and religious holidays, which are

7 "Łaknie jak kania dżdżu" (Pióro 2012, 59), "wants the rain as the kite does" (free translation by the author). celebrated, and their consequences for men. Since the beginning, man admired nature, being afraid of its wildness and its primaeval power. When one joined it with God, it aroused fear even more, but also a greater fascination.

Nature is always present, always meaningful. Nature does not have to go to church or pray by using words of well-known prayers; it lives in a way it was destined to be, by the laws God has given to it. There is a very interesting poem by a Polish poet-priest Jan Twardowski, who writes that trees do not believe, birds do not learn religion at schools, dogs rarely go to church, insects do not read the Gospels, but they are all pure, humble, and righteous (Twardowski 2021a). They are the essence of holiness.

In the early days, animals, including birds, were creatures people wanted to understand to find the meaning of life on this planet, and try to have control over the world. Here, one can notice a kind of a paradox, though in the past, animals were the main source of food, people from folk tales treated them with due respect. They learnt from them, observed their behaviour, looking for signs and clues how to live, and when is the right time to perform certain activities, in order to harvest more crops or simply be healthy and enjoy life.

Nowadays, we cut trees, making concrete islands from our countries, calling ourselves the most important beings in the world. Is that so, are we really the centre of everything? In modern times, birds are on cups, T-shirts, and cosmetics, they are omnipresent in our pop culture, but they do not have our true interest and admiration as they used to have. They stay unnoticed, sometimes as tools, without any metaphysical value. Now, when something is inexplicable, we have the tendency to abandon the topic, or call it simply "magic" in a pejorative way. In folk tales of old, one can find various ways of explaining things. From our modern perspective, many of their authors were incorrect or naive, but they made an effort to do so and, what is more, they tried to combine 
their knowledge from observation and experience with their beliefs. Today, we know that swallows migrate when autumn comes, and they do not immerse into water, partridges do not steal eggs or chicks from one another, and the phoenix does not exist. These were not scientific observations, and had nothing to do with science, but somehow, they still make our imagination flourish, take us to another dimension, give us a different perspective. What was unknown or mysterious to people who wrote folk tales, was immediately completed with stories of saints or divine powers, being humble towards Nature, and pious at the same time. This specific kind of balance was far more important to them than scientific explanation, especially pointing to the fact that those people were not adequately educated in that matter. Now, we know more and with precision, because we have the tools to explore everything thoroughly, but simple folk could describe every phenomenon in such detail, giving themselves space not only for the body, but also for the soul. Many early ideas indicated directions for modern people to start with, many of them are still a mystery, and maybe they will always be some kind of enigma. Maybe it is supposed to be like this, following the myths, and I dare to say that stories of my present research are something we are all seeking in our lives. As Campbell suggests: "our life experiences on the purely physical plane will have resonances within our own innermost being and reality, so that we actually feel the rapture of being alive. That's what it's all finally about, and that's what these clues help us to find within ourselves" (Campbell 1991, 9).

My research has shown that men had a tendency to give animals human features, especially when moral values were to be presented and absorbed. Although, from a biological or scientific point of view, some species of birds can be very protective and smart, many stories are nothing more but exaggerated, moralising images of them.
The Polish saying "smart as an owl" in reality, does not indicate that owls are very wise birds, but they have a certain feature they can look a man straight in the eyes, because of the bird's eyes' position on the head, hence, the owls face resembles human face, and humans are wise. Who counted the strikes of a rooster's wings or a crane's twisted movements of its neck? Is it really 3 ? As a person interested in phenology, I know that there are some years when larks come very early, before Saint Agnes "decides" to release them from her sack; many birds which migrated decades ago, now, since the dramatic changes in climate, stay in our country, and survive. However, even today, in pop culture, we are trying to make animals look and behave like people in animated movies, books, and commercials very little has been left from their wildness and variety. We do not rely on animals such as birds, we do not have to search for their guidance as harbingers or omens, we have equipment and methods to predict weather, to distinguish the seasons, to celebrate holidays, though we may not realise that there are still some rituals behind our actions. Old tales resemble the myths themselves: sacred and profound, the foundation of being, whilst medieval bestiaries considered birds as an explanation for moral virtues and the model of life, nowadays, we somehow abandon the divine and turn it into something which is earthbound "interested in the news of the day and the problems of the hour" (Campbell 1991, 13). People from folk stories treated birds as mystical creatures, helping them to find answer to various questions, even the existential ones. Today, birds seem to be only utilitarian or consumptive.

I will end my considerations about Nature and myths with three more poems by Twardowski. $16^{\text {th }}$ of July is a day of remembrance of the Lady of Mount Carmeland there are few who remember it. Jan Twardowski

8 "Sowa mądra głowa", "smart like an owl" (free translation by the author). 
writes that when even all people, even the computers, forget about this holy day, the cuckoo will remember it, since there is a saying that this bird becomes silent after that day (Twardowski 2021b). Twardowski admires the beautiful, rare bird roller, and through that God's creature, he admires God himself, because only God could create such a beauty with blue wings, almost a black tail and cinnamon back (Twardowski 2021c). In one of Twardowski's poems, there is an explanation why God created all of this - He did it to get to know Himself better. While creating birds, plants, and man, God found out that $\mathrm{He}$ is omniscient (Twardowski 2021d). In Christian values and the figures of saints, people found the missing piece, the answers they were looking for. The element of divine intervention helped them in better understanding of the complexity of life and together with their observation of nature, it made a whole. Still, mythology is a "life-nourishing subject" (Campbell 1991, 23), since we see it in fantasy films and books which are now very popular. We want to hear old people from our families telling the stories "soaked" with magic, because they contain truth and food for the soul, and we cannot deny that we still need it.

\section{Funding: This research received no external funding.} Institutional Review Board Statement: Not applicable.

Conflicts of Interest: The author declares no conflict of interest.

\section{References}

Bates, Brian. 2005. Magia i tajemnice średniowiecza. [Magic, myths and mysteries of the Middle Ages]. Warszawa: Dom Wydawniczy Bellona.

Bruce-Mitford, Miranda. 1997. Ilustrowana Ksiega Znaków i Symboli. [The Illustrated Book of Signs and Symbols]. Warszawa: Wydawnictwo Arkady. Chadd, Rachel W., and Marianne Taylor. 2016. Birds. Myth, lore and legends, Bloomsbury Publishing Plc. Karczewski, Jacek. 2014. Noc Sów. Bądź na pTAK! Ogólnopolska Kampania Wiedzy i Edukacji Przyrodniczej. [Night of the Owls. Be on the bird (Yes)! Polish National Knowledge and Life
Education Campaign]. Edycja 3. Stowarzyszenie Ptaki Polskie.

Kowzan, Jacek. 2007. "Kogut, czyli przyczynek do pewnej zwierzęcej ambiwalencji w kulturze." [Rooster, or a contribution to a certain animal ambivalence in culture]. In Bestie, żywy inwentarz i braci mniejsi. Motywy zwierzęce w mitologiach, sztuce $i \dot{z y c i u}$ codziennym, [Beasts, livestock and lesser brothers. Animal themes in mythology, art and everyday life], edited by Piotr Kowalski, Katarzyna Łeńska-Bąk, Magdalena Sztandara, 121-132. Opole: Uniwersytet Opolski. Opolskie Towarzystwo Przyjaciół Nauk.

Kruszona, Michał. 2008. Kulturalny Atlas Ptaków. Poznań: Zysk i S-ka Wydawnictwo.

Libera, Zbigniew. 2007. "Zapiski ornitologiczne Kazimierza hr. Wodzickiego." [Ornithological notes of count Kazimierz Wodzicki]. In Bestie, żywy inwentarz i braci mniejsi. Motywy zwierzęce w mitologiach, sztuce i życiu codziennym, [Beasts, livestock and lesser brothers. Animal themes in mythology, art and everyday life], edited by Piotr Kowalski, Katarzyna Łeńska-Bąk, Magdalena Sztandara, 209-214. Opole: Uniwersytet Opolski, Opolskie Towarzystwo Przyjaciół Nauk.

Moyers, Bill. 1991. Joseph Campbell. The Power of Myth. New York: Bantam Doubleday Dell Publishing.

Pawłowska, Krystyna. 2003. "Zwiastowanie Pańskie w tradycji ludowej”. Niedziela wtoctawska 12/2003. Accessed May 1, 2021. https://www.niedziela.pl/artykul/13457/nd/ Zwiastowanie-Panskie-w-tradycji-ludowej.

Peregryn z Opola. 2003. "Kazanie na Wielki Piątek." [The Annunciation of the Lord in the folk tradition]. In Peregryn z Opola, Kazania de tempore $i$ de sanctis, [Homilies de tempore and de sanctis], translated by Jerzy Wolny, and Julia Mruk, 140146. Kraków: Papieska Akademia Teologiczna.

Pióro, Marek. 2019. Kalendarz Ptaków. Opowieści o ptasim życiu i zwyczajach na caty rok. [Bird calendar. Tales of bird life and habits for the whole year]. Kielce: Wydawnictwo Paśny Buriat.

Rosiński, Franciszek M. 2007. "Zwierzęta w ujęciu biblijnym." [Animals from the biblical perspective]. In Bestie, żywy inwentarz i braci mniejsi. Motywy zwierzęce w mitologiach, sztuce i życiu codziennym, [Beasts, livestock and lesser brothers. Animal themes in mythology, art and everyday life], 
edited by Piotr Kowalski, Katarzyna Łeńska-Bąk, Magdalena Sztandara, 49-72. Opole: Uniwersytet Opolski, Opolskie Towarzystwo Przyjaciół Nauk. Sasor, Rozalya ed. 2006. Bestiariusz. [Book of Beasts]. Kraków: Księgarnia Akademicka.

St. Ambrose. Maker of all, eternal king. Translator: Wiliam J. Copeland. Calvin Institute of Christian Worship. Accessed June 18, 2021. https://hymnary. org/text/maker_of_all_eternal_king.

St. Thomas Aquinas. 2017. Humby I Adore Thee, Hidden Deity. Accessed August 17, 2021. https:// tosingistopraytwice.wordpress.com/2017/04/06/ humby-i-adore-thee-hidden-deity/.

Tańczuk, Agnieszka. 2010. "Groza pół-śmierci w powieści Wtadca Pierścieni J.R.R. Tolkiena.” [The dread of half-death in the novel 'The Lord of the Rings' by J.R.R. Tolkien]. In Groza. Spoteczno-kulturowe mechanizmy kreowania emocji, [The dread. Socio-cultural mechanisms of creating emotions], edited by Bożena PłonkaSyroka, Marek Szymczak, 159-182. Wrocław: Oficyna Wydawnicza Arboretum.

Twardowski, Jan. 2021a. "Drzewa niewierzące." [Unbelieving trees]. Accessed July 01, 2021. https:// literatura.wywrota.pl/wiersz-klasyka/24733ksiadz-jan-twardowski-drzewa-niewierzace.html. Twardowski, Jan. 2021b. "Kukułka." [Cuckoo]. Accessed July 01, 2021. https://www.apostol.pl/ twardowski/poezja/kuku\%C5\%82ka.

Twardowski, Jan. 2021c. "Kraska." [Roller]. Accessed July 01, 2021. https://literatura.wywrota.pl/wierszklasyka/41047-ksiadz-jan-twardowski-kraska. html.

Twardowski, Jan. 2021d. "Stwarzał." [Creation]. Accessed July 01, 2021. https://literatura.wywrota. pl/wiersz-klasyka/41248-ksiadz-jan-twardowskistwarzal.html. 